\title{
POST-TRUTH, MEDIA SOSIAL, DAN MISINFORMASI: PERGOLAKAN WACANA POLITIK PEMILIHAN PRESIDEN INDONESIA TAHUN 2019
}

\author{
MOCHAMAD IQBAL JATMIKO
}

Departemen Sosiologi, Fakultas Ilmu Sosial dan Ilmu Politik Universitas Gadjah Mada

Email : mochamad.iqbal.j@mail.ugm.ac.id

\begin{abstract}
:
Today, positivistic in the political sphere has been invaded by the notion of relativism. The post-truth regime bursts into political discourse and public awareness. Community opinion is driven in distrust of objective data. Reality manipulation is increasingly being carried out for political purposes. In this condition, the community is more secure with pseudo-facts that match personal beliefs. The discourse of political lies is then packaged into alternative discourses to match objective facts. The development of massive information technology, through online media, helps the distribution of discourse in the community. Public awareness through opinion is built and new facts are created. This is how Indonesian political contestation in 2019 is full of strange discourses without data. Political recitals are chaotic because of the disparity among factions that spread lies, hatred, and nonsense. Community elements are exploited for the sake of discourse battle victory. Like passive objects that are annihilated, people are made slaves to win the political elite.
\end{abstract}

Keywords: Social Media, Political Discourse, Post-Truth, Misinformation

\section{PENDAHULUAN}

Gagasan rezim post-truth menjadi semakin substansial dalam menggambarkan kehidupan politik karena masifnya perubahan masyarakat ke arah digitalisasi. Istilah post-truth hampir tidak dikenal sekitar 5 tahun yang lalu, tetapi mulai berkembang ke panggung media baru-baru ini. Menurut Keyes (2004) istilah post-truth sebenarnya sudah muncul sejak 2004 sebagai pengaburan batas antara berbohong dan pengungkapan kebenaran. Akan tetapi, fenomena post-truth menjadi perhatian publik sekitar November 2016 ketika Kamus Oxford menamakannya di tahun 2016. Inisiasi tersebut digagas setelah melihat lonjakan penggunaan kata post-truth yang mencapai 2.000 persen selama tahun 2015 (Mclntyre, 2018: 1).

Eksisnya diskursus rezim post-truth di Indonesia berawal dari pernyataan 
Jokowi tentang suasana politik yang dijejali dengan pelbagai kabar bohong secara berulang sehingga post-truth benar-benar terjadi (lihat Majalah Tempo, 27 April 2019). Kondisi tersebut berkaitan dengan keadaan fakta objektif kurang berpengaruh dalam membentuk opini masyarakat daripada menarik emosi dan kepercayaan (Feldman, 2017; Hendricks dan Vestergaard, 2019). Rombongan gerakan dan tokoh populis otoriter dengan gencar berusaha menurunkan kepercayaan pada arus media dan pengetahuan ahli sehingga tumbuh subur media alternatif sebagai entitas wacana tandingan (Harsin, 2015; Tallis, 2016).

Ketika memahami konsep post-truth penting sekali untuk mengeksplorasi perubahan dengan mempertimbangkan prasyarat psikologis, sosial, teknologi, dan konteksnya. Menyoal di Indonesia, transformasi media tradisional menuju digital menduduki posisi vital masyarakat. Seluruh elemen kehidupan sosial telah beresonansi dengan lingkungan media baru; bahkan media sosial bertindak dominan. Oleh karena itu, tidak mengherankan bahwa pengaruh munculnya internet dan platform media sosial yang beragam membuat penyebaran berita palsu semakin intensif (Bhaskaran, Mishra, dan Nair, 2017: 42).

Tendensi tren masyarakat ke ranah media sosial telah berkontribusi pada gencarnya dunia post-truth selama beberapa dekade terakhir. Tampak dari elite politik di beberapa penjuru dunia yang menggunakan wahana media sosial untuk memanipulasi paradigma masyarakat melalui fakta alternatif ataupun gosip jahat tentang lawan dengan asumsi sedikit bukti sehingga mendorong penyebaran kebodohan (Block, 2019: 60). Oleh sebab itu, tugas dalam tulisan ini adalah untuk melihat perubahan yang telah terjadi dalam bidang komunikasi politik serta bagaimana perubahan itu menggambarkan kondisi masyarakat yang lebih luas.

Artikel ini menggunakan konteks peristiwa publik tentang pemilihan presiden Indonesia tahun 2019 untuk mengejar sejumlah pertanyaan: Bagaimana peran media sosial dalam wacana politik di rezim post-truth? Sejauh mana ancaman media sosial dan misinformasi di rezim post-truth?. Artikel ini mengeksplanasi temuan dari penelitian kualitatif melalui wacana yang disebarkan media sosial ke dalam konteks sosial-politik yang kompleks. Penulis menunjukkan beberapa analisis wacana kritis yang disampaikan oleh koalisi politik untuk memahami kebimbangan yang berkembang dalam wacana publik. Hasil temuan nantinya diharapkan mampu menyimpulkan dengan memberikan beberapa petunjuk tentatif untuk solusi yang mungkin dapat dipraktikan.

\section{HASIL DAN PEMBAHASAN}

\section{Perenungan Post-truth : Kondisi Zaman Kita}

Situasi perpolitikan Indonesia, sekitar tahun 2018 sampai pasca-pemilihan presiden 2019, dipenuhi dengan berbagai wacana yang menjenuhkan. Mulai dari 
distorsi figur calon presiden, kecurangan pemilu melalui quick count, dan pembenaran atas people power. Wacana yang digaungkan oleh elite kepentingan hanya sebatas pertarungan retorika politis, bukan pada kompetisi gagasan, ide, dan kebijakan arah bangsa Indonesia kedepan. Menariknya, wacana-wacana kosong tanpa landasan data mendapatkan animo luar biasa dari para antek militan (Cebong dan Kampret). Melalui diskursus tanpa data, persepsi masyarakat direkonstruksi dan secara bertahap fakta alternatif diciptakan sehingga post-truth berlangsung. Budaya politik post-truth ditandai oleh perspektif relativis yang merendahkan klaim kebenaran dari pendirian politik dan arus utama media. Seluruh kebenaran dianggap sebagai opini atau ungkapan kepentingan pribadi yang tersembunyi (Prozorov, 2018).

Demokratisasi ruang publik di Indonesia — sedang berlangsung - mulai terongrong oleh devaluasi kebenaran. Kondisi tersebut akan membuka jalan bagi munculnya gerakan post-truth radikal, seperti kebohongan, obskurantisme, dan ekstremisme. Situasi demikian dimanfaatkan oleh elite partai yang berebut kemenangan untuk menuduh lembaga-lembaga quick count sebagai pembohong (lihat Nurita dan Persada, 2019; nasional.tempo.co). Retorika dan omong kosong menjadi pusat alternatif dalam mengambilalih kesadaran publik. Menurut Fredal (2011: 245) retorika dan omong kosong hadir untuk berbicara, tidak hanya untuk membentuk dan memengaruhi kounikator, komunikan, kesepahaman, dan relasi keduanya, melainkan juga membangun elemen masing-masing secara berkelanjutan melalui negosiasi; menekankan sentralitas respons audiens sebagai akhir dari setiap pertemuan yang diberikan. Akibatnya, paradigma individu cenderung bergantung pada ideologi daripada bukti.

Omong kosong dan retorika memiliki korelasi yang kuat, sebab seperti retorika, omong kosong mengandaikan pembicara, pendengar, dan teks yang memberlakukan karakteristik pertukaran simbolik dari bahasa sedang digunakan. Keduanya selalu berurusan dengan bahasa yang tidak etis dalam kaitannya dengan kontinum epistemologis yang mencakup kebenaran. Dimensi kebohongan, kekeliruan, dan kesalahan ganda diakui sebagai strategi retoris yang salah dan tidak etis karena mereka dapat dibandingkan secara tidak menguntungkan dengan pendapat yang beralasan dan kebenaran universal (McComiskey, 2017: 7-8). Akan tetapi, strategi penekukan realitas tersebut ditempuh — secara berulang - dalam ranah politik untuk menipu pendengar yang kurang peduli terhadap kebenaran sehingga mengubah persepsi publik sesuai dengan persepsi kelompok kepentingan (Fredal, 2011: 245).

Salah satu hakikat yang tidak berubah dalam omong kosong dalam rezim post-truth adalah tidak adanya relasi dengan fakta, realitas, dan kebenaran di antara retorika politik. Mayoritas publik dianggap sebagai khalayak lemah karena rentan terhadap omong kosong. Kondisi demikian dimanfaatkan sebagai wahana destabilisasi atau bahkan penghancuran gagasan kebenaran. Tallis (2016: 8-9) 
menjelaskan bahwa politisi post-truth bermain untuk suasana yang meluas dan semakin sinis, anti-pakar, anti-pendirian, dan anti-otoritas, tetapi yang jelas juga masih sangat membutuhkan kepemimpinan dan ambisi. Oleh sebab itu, rezim post-truth dapat diciptakan dengan efisiensi khusus ketika aktor politik yang kaya sumber daya berusaha untuk mengelola bidang penampilan dan partisipasinya. Pada dasarnya, populasi yang sesuai dengan kepercayaan dan pendapat direncanakan, diproduksi, dan dikelola oleh analitik prediktif yang digerakkan oleh komunikasi strategis dengan tujuan untuk memastikan bahwa narasi yang sedang dibangun sesuai dengan prakonsepsi khalayak, prasangka, dan keinginan yang paling mendesak sedekat mungkin, sehingga hampir menjamin keberhasilan pewacanaan kelompok (Harsin 2015: 330-331).

\section{Media Sosial Mengatasi Kelesuan Produksi dan Distribusi Post-truth}

Media sosial sebagai bagian dari new media telah memberikan pemahaman baru bahwa kekuasaan bekerja di seluruh aspek kehidupan manusia, termasuk dalam ruang virtual. Sejalan dengan itu, Shapiro (1992) mengatakan bahwa dalam pembentukan suatu wacana diperlukan adanya politik ruang (a politics of space) sebagai ranah pertarungan wacana terjadi; wacana utama (main discourse) dengan wacana tandingan (counter discourse). Media sosial menjadi alat yang menanamkan konsep kebenaran dan memungkinkan penciptaan rezim wacana yang berpotensi membingkai kepentingan menjadi sebuah fakta. Implikasi yang sangat mungkin terjadi adalah terbentuknya ekosistem media sosial yang diproduksi dan bersifat hierarkis. Sebagaimana analogi Hannan (2018: 219) yang memproyeksikan media sosial Facebook sebagai kontes popularitas sekolah menengah, sedangkan Twitter sebagai halaman sekolah yang dikelola oleh para pengganggu.

Media tradisional dan demokratisasi ruang publik yang sepenuhnya belum terwujud memberikan angin segar pada platform online untuk memainkan peran penting ceruk politik dan representasi non-mainstream. Ruang virtual menjadi ruang yang tepat untuk konstruksi, promosi, dan penyebaran politik dengan gaya komunikasi populisme (Copsey, 2003; KhosraviNik, 2018). Media sosial dapat memfasilitasi pertemuan dengan konten politik di antara pengguna yang kurang terlibat secara politik sehingga dapat mendorong individu untuk diskusi politik yang pada gilirannya memobilisasi untuk tindakan politik (Valeriani dan Vaccari, 2016). Artinya, pertukaran informasi berpotensi menjadi instan, secara nasional maupun global. Media baru mengubah dimensi ruang dan waktu arus komunikasi, interaksi manusia, dan proses pengambilan keputusan (Abrahamson et al., 1990: 42-45). 
Transformasi digital dalam post-truth mengindikasikan bahwa peluang ekspresif dan diskursif yang ditawarkan oleh social network sites. Keterlibatan langsung dalam aktivitas online dapat melepaskan emosi dan perasaan keterlibatan; pada gilirannya memfasilitasi mobilisasi publik yang terhubung secara digital, didorong oleh status afektif bersama dan pendapat yang sejalan (Papacharissi, 2015: 8). Dalam hal ini, budaya masyarakat telah bergeser dengan menerima kehadiran suatu fenomena online sebagai kebetulan dengan kebenarannya sendiri. Logika tersebut dapat diperluas untuk memungkinkan fenomena online berfungsi sebagai peristiwa di dalam dirinya sendiri tanpa berhubungan dengan peristiwa atau pengalaman aktual (Sawyer, 2018: 63).

Kebenaran di rezim post-truth yang semakin semu akibat mediasi teknologi dapat menjerumuskan pada kebohongan, kepalsuan, dan misinformasi masyarakat. Penulis berita palsu mulai gemar menyusun narasi yang sensasional, baik untuk menghasilkan uang dari iklan ataupun untuk mendeskripsikan kualitas memalukan kepada orang-orang tertentu; biasanya lawan politik. Hasil narasi kebohongan kemudian di posting, tweet, dan tag dalam platform media sosial yang tanpa konteks untuk dikritik dan dinilai (McComiskey, 2017: 17-18).

Seiring dengan itu, kelompok trolling juga muncul dari sudut kelam media sosial (lihat Buckels, Trapnell, dan Paulhus, 2014; Craker dan March, 2016; Synnott, Coulias, dan Ioannou, 2017). Trolling melibatkan kombinasi penipuan, agresi, dan gangguan wacana online yang tampaknya tidak masuk akal. Troll dianggap menyebabkan kekuatan negatif dan pengaruh atas orang lain dengan menciptakan kekacauan sosial maupun interaksi interpersonal negatif (Craker dan March, 2016). Dilambangkan sebagai pengguna anonim yang akan meninggalkan komentar kejam, menyakiti, menyinggung dan menabur perselisihan publik. Di balik tabir profil palsu, anonimitas akan melepaskan naluri buruknya; rasisme, kebencian terhadap feminisme, homofobia, transphobia, islamophobia, dan sejenisnya (Ott, 2017; Hannan, 2018).

Segregasi komunitas virtual — grup di media sosial— lambat laun dibentuk, baik untuk aktivisme politik maupun gerakan masyarakat. Komunitas semacam itu cenderung disatukan oleh beberapa keinginan, minat, dan konsepsi bersama tentang dunia. Dengan kata lain, jejaring yang dibangun mencoba memvalidasi dirinya sendiri melalu reproduksi keinginan, minat, dan konsepsi dunia (McGranahan 2017: 246). Faktor-faktor struktural dalam mode media sosial berkontribusi pada mobilisasi kebenaran yang bersifat afliatif. Menurut Kalpokas (2019: 27) tendensi argumentasi komunitas virtual lebih terstruktur secara alogaritmatis. Sebab, media sosial secara otomatis akan menyeleksi konten yang ditampilkan kepada pengguna — memberi konten berdasarkan pola perilaku sebelumnya - sehingga membatasi paparan pada konten yang tidak sesuai dengan aktivitas atau pencarian sebelumnya.

Seleksi algoritmik akan memastikan individu terdampak struktur informasi 
sesuai dengan pandangannya sendiri (Lewandowsky et al., 2017). Sependapat dengan Kalpokas (2019: 123-124) tentang personalisasi dari dunia virtual yang memungkinkan otomatisasi algoritma untuk memberikan jawaban yang dibuat khusus sehingga personalisasi kebenaran memungkinkan untuk hidup di dunia yang tampaknya dibuatnya sendiri. Singkatnya, individu menciptakan gelembung pengelompokan virtual sehingga terus-menerus terpapar ke satu sisi narasi. Fleksibilitas dan fraksinasi yang ditawarkan oleh media sosial telah memungkinkan orang untuk memilih ruang gema karena sebagian besar informasi tersedia - sesuai dengan sikap yang sudah ada sebelumnya. Salah satu konsekuensi dari paparan media sosial tersebut lebih pada pembentukan kepercayaan yang tidak akurat; bahkan ketika bukti yang relevan dipahami dengan benar (Garrett, Weeks, dan Neo, 2016; Laybats dan Tredinnick, 2016).

Dengan demikian, komunitas atau anggota dalam media sosial akan melakukan validasi diri dalam gelembung-gelembung udaranya sendiri. Cara tersebut akan memungkinkan untuk menguatkan persprektif dirinya sehingga mengarah pada radikalisasi yang lebih dalam dan mengakar dalam pandangan seseorang. Tidak mengherankan bahwa media media sosial dapat dianggap sebagai alat penting yang dapat digunakan untuk membentuk sikap dan perilaku publik oleh elite kepentingan politik (Biały dan Svetoka, 2016: 30).

\section{Komunikasi Politik dan Diskursus di Era Post-truth}

Platform media online, seperti twitter, facebook, google, youtube, instagram, dan lainnya, mulai mentransmisikan model baru komunikasi politik. Teknologi Media Sosial telah berpengaruh terhadap norma-norma komunikasi politik secara umum, khususnya pada aktivisme politik Indonesia. Media yang cukup strategis untuk arena pertarungan, yaitu twitter melalui tagar politik (lihat Azanella, 2019; kompas.com) dan facebook dengan pelbagai berita palsu (lihat Bhaskaran, Mishra, dan Nair, 2017; Ariyanti, 2019; merdeka.com). Melalui akun media online tersebut, pengguna dapat menjadi bagian dari produksi, konsumsi, dan distribusi konten tanpa hambatan (KhosraviNik, 2014). Selain itu, peningkatan peluang komunikasi politik individu berdampak pada relasi berjejaring dengan orang lain yang berpikiran sama dan membantu mengorganisir kedalam tindakan kolektif. Intensitas komunikasi politik yang matang nantinya juga memengaruhi keterlibatan politik publik (Shirky, 2008; Kelm dan Dohle, 2018).

Awalnya, hakikat peran media digunakan sebagai trajektori komunikasi politik antara pemerintah dan warga negara. Mayoritas masyarakat Indonesia memperoleh informasi politik melalui berbagai jenis penggunaan media, baik tradisional ataupun digital. Informasi politik yang diperoleh memiliki efek kuat 
pada sikap warga terhadap politik, sebab persepsi individu tentang kondisi perpolitik nasional biasanya dijelaskan oleh sumber media. Wacana politik yang dimediasi dapat menembus diskursus politik interpersonal dan mengubah minat individu dalam politik sehingga warga negara dapat memengaruhi evaluasi terhadap demokrasi negara; memengaruhi penilaian publik (Eveland 2004; Chang, 2018). Lebih khusus lagi, kondisi politik dewasa ini semakin disokong oleh kemajuan teknologi informasi. Transformasi komunikasi politik antara pemerintah, partai politik, dan warga negara telah banyak berubah secara digital dan pergerakannya menjadi lebih cepat (Boulianne 2011; Chang, 2017).

Kemudahan akses komunikasi politik dan pengaruh kehidupan masyarakat melalui wacana post-truth tampaknya memberikan pengaruh positif terhadap kepentingan politik. Meningkatnya frekuensi para pemimpin politik dan persebaran fakta alternatif dalam media online beberapa tahun terakhir, mendorong munculnya gerakan politik yang mengandalkan daya tarik emosional atau opini tanpa data daripada diskusi berbasis fakta kebijakan (Romano, 2017; Strong, 2017). Media sosial online membentuk kembali komunikasi yang kontroversial dan memobilisasi individu untuk berpartisipasi dalam kegiatan gerakan sosial (Gerbaudo, 2012). Misalnya, berita bohong tentang adanya tujuh kontainer surat suara tercoblos; kasus tentang kekalahan kubu Prabowo-Sandi yang diparadokskan dengan wacana tandingan berupa hasil kemenangan oleh TKN Prabowo-Sandi yang tidak memiliki data yang sahih; memobilisasi massa melalui delik people power, dan wacana-wacana politis lainnya.

Wacana omong kosong menjadi salah satu cara yang dilakukan oleh TKN Prabowo-Sandi untuk meng-counter kemenangan TKN Jokowi-Ma'ruf. Melalui media online, wacana diproduksi dan disebarkan secara berulang demi membangun kondisi emosional masyarakat. Sebab, mayoritas masyarakat tampaknya lebih suka menerima informasi yang diedit dan dikemas oleh orang lain daripada memilah-milah informasi dalam jumlah besar. Bahkan Internet semakin menawarkan informasi yang dikemas dengan bagian-bagian mengadopsi format media massa (Louw, 2005: 124). Selain itu, pihak pembuat wacana alternatif dapat menurunkan biaya yang diperlukan untuk memengaruhi opini melalui berita dan informasi tentang urusan kebohongan publik.

Rezim post-truth sangat memungkinkan untuk politisi sekarang secara rutin saling melakukan trolling di media online sebagai komunikasi politik. Warga men-troll politisi dan politisi semakin men-troll kembali. Sebagai genre baru dalam komunikasi politik, trolling telah menjadi umum sehingga norma-norma dan harapan-harapan baru dengan cepat berkembang di sekitarnya. Trolling politik telah menjadi tontonan media; layak untuk liputan berita yang lengkap. Para komentator media sekarang membedakan yang lebih baik daripada yang lebih buruk. Sumber-sumber berita partisan merayakan dengan gembira ketika politisi pilihannya ahli dalam menangkap politisi saingan. Perspektif trolling tidak lagi 
dipandang sebagai hal yang buruk dalam suasana carut-marutnya politik Indonesia. Lingkungan diskursif baru dipenuhi kebisingan dan logika penghinaan. Siapa pun yang menghina paling frontal dan mengerikan akan menjadi pemenangnya (Hannan, 2018: 221).

\section{Pembingkaian Cerita sebagai Fiksi Buatan Bersama}

Aspek lanjutan dari wacana politik pemilihan presiden Indonesia di rezim post-truth tampaknya mengemban peningkatan fluiditas persekutuan. Problematikanya bukan sebatas fakta yang tidak penting, tetapi semuanya dapat diubah menjadi kawan atau lawan. Netralitas bukanlah suatu pilihan yang menentramkan, tetapi berisiko menjadi umpan pertarungan. Ilmu pengetahuan, jurnalisme, dan hukum sudah dipolitisasi; dikategorisasi secara biner sebagai teman atau musuh. Anda baik bersama kami atau melawan kami; jika Anda melawan kami, maka Anda adalah berita palsu (Hendricks dan Vestergaard, 2019: 105). Tampak bahwa narasi politik rezim post-truth bukan sebatas distorsi realitas yang mendasarinya; lebih tepatnya dianggap sebagai pembangun realitas paralelnya sendiri (Sloman dan Fernbach 2017 : 261).

Narasi palsu menjadi bentuk retorika post-truth yang berbahaya dalam konteks negara karena sebagai narasi alternatif dalam dunia kehidupan masyarakat. Ditambah dengan dampak media sosial secara eksponensial meningkatkan problem kesalahan informasi dan pikiran picik. Sebab, platform media sosial memberikan konten yang sudah disetujui publik dan mendorong pengelompokan sosial ideologis. Pada lahirnya, membatasi pertemuan dengan berbagai ide universal yang dapat menantang keyakinan absolut (McComiskey, 2017: 19). Kompleksitas tersebut kemudian mengelaborasi konstruksi peristiwa diskursif sehingga menciptakan kebenaran esoteris, kebohongan, kekeliruan, dan penyebaran omong kosong yang disengaja.

Setidaknya, wacana politik dengan dasar kebohongan dibingkai melalui dua cara. Pertama, berkonsentrasi pada media, yaitu jurnalisme. Pembingkaian masalahnya dilakukan dengan melihat berita palsu sebagai penyebab utama yang dikemas secara sempurna. Dalam hal ini, pengecekan fakta dipersulit untuk menjaga kualitas berita palsu yang disebarluaskan. Kedua, membingkai masalah dengan fokus pada media, yaitu pada teknologi komunikasi. Caranya dengan menganggap media sebagai yang dominan pada konteks zaman itu, bukan kontennya sebagai penyebab utama. Dengan kata lain, memahami peran dominasi media yang membentuk opini publik - tidak hanya konten tetapi seluruh struktur wacana publik yang afektif - sehingga masyarakat merasakan parahnya kekacauan saat ini (Hannan, 2018: 215).

Sepertinya, jenis analisis wacana politik seperti ini paling sesuai untuk 
masa-masa sekarang, di mana keberhasilan aktor politik di era post-truth bergantung pada elemen kunci dari critical discourse studies sebagai komunikasi politik (Block, 2019: 78). Selain itu, kemudahan akses teknologi informasi mendorong individu untuk membuat dan menyiarkan medianya sendiri. Pada tahapan tersebut, media sosial menekankan sampai pada titik distopia logis virtual melalui hubungan ideologi dengan realitas. Peristiwa dapat dibuat dari seluruh pemikiran yang dibingkai sedemikian rupa sehingga sesuai dengan etos subjek yang menggunakan fenomena tersebut. Dengan kata lain, tidak ada yang benar-benar terjadi kecuali peristiwa yang diabadikan pada jaringan media sosial dengan membawa gagasan otoritas (Sawyer, 2018: 63).

\section{Dentuman Informasi ke Pengalaman Emosional}

Percepatan arus distribusi informasi di Indonesia tampaknya benar terjadi. Gerakan informasi tidak dapat dibendung lagi, budaya masyarakat juga mulai bertransformasi secara cepat (Virilio, 1986). Masyarakat banyak menemukan referensi informasi dari pelbagai media, khususnya media online. Akumulasi pengetahuan dan informasi yang disimpan pada abad ke-19 telah menyebabkan ketidaktahuan yang sama besarnya. Ketika ada begitu banyak yang harus diketahui karena banyaknya bidang pengetahuan dan informasi. Kata-kata yang sama digunakan dengan makna yang berbeda. Ketika seseorang mengetahui sedikit tentang pengetahuan maka akan menyulitkannya untuk beradaptasi dengan ledakan informasi. Ketidaktahuan atas kebaharuan informasi yang berkembang, akhirnya menstimulasi individu untuk mengganti pikiran dengan emosi (Elliot, 1920: 9).

Di dunia post-truth rasionalitas individu dipotong kemudian digiring dalam naluri informasi online. Audiensi cenderung tidak mencari informasi yang menjadi dasar pendapatnya, tetapi mencari kebenaran pendapat yang mendukung keyakinannya sendiri. Saat ini, semuanya berada dalam cengkraman ketidakrelevanan fakta, realitas, dan kebenaran. Bahasa semakin dieksploitasi oleh retorika tanpa landasan atau referensi yang jelas. Omong kosong relatif sederhana di dunia pre-post-truth, namun kini telah berevolusi, post-truth menjadi serangkaian strategi retorika yang kompleks, termasuk berita palsu (McComiskey, 2017: 12-13). Saling menghujat, penyerangan berita palsu, bahkan paradoks realitas pun terjadi. Berita palsu versi kepentingan yang didramatisir dan sensasional berbondong-bondong mendapatkan trending topic di media dan rasio masyarakat, sebab pernyataan wacana politik diperhitungkan dengan cermat untuk mendapatkan perhatian publik (Davis, 2017: xii).

Wacana politik di era post-truth mengambil peran sentral dalam mengakomodir kebutaan akal sehat yang disengaja dan menarik argumen berbasis emosional. Keduanya sering berakar pada kecemasan problema di masyarakat; mewakili keprihatinan nyata dan pengalaman hidup (Laybats dan Tredinnick, 
2016: 204). Argumen yang berkembang lebih jauh lagi biasanya mencakup bentuk statistik, informasi historis, dan kerangka lain dari bukti ambivalen yang dapat diverifikasi tetapi menggunakan prosedur yang berbeda secara konteks maupun makna (Romano, 2017: 52). Berdasarkan keyakinan dan muatan emosional dalam pembentukan wacana politik, fakta objektif akan kalah dengan kebenaran emosional. Dampaknya, diskursus politik Indonesia tidak lagi mengacu pada wacana rasional yang sehat.

Lebih lanjut, promosi wacana kebohongan dipoles dengan baik supaya kebenaran emosional mampu menerobos pengulangan pelaporan dan menarik perhatian. Dalam hal ini, pengemasan dan branding memang lebih penting daripada konten. Oleh sebab itu, topik-topik kontroversial, ketidakadilan politis, sarkasme, ejekan, dan rasa tidak hormat terhadap aturan-aturan sangat digemari pewacana, sebab pontensial untuk menarik perhatian audiens dan memaksimalkan pengalamannya. Dalam konteks itu, penggunaan isyarat emosional membantu mendapatkan perhatian peonton dan mendorong keberlangusungan keterlibatan individu (Suiter 2016: 27). Sinisme epistemologis politis yang terbentuk kemudian membangun kepercayaan ideologis yang dipegang teguh, bahkan ketika klaim pendukung terbukti salah.

Beginilah kondisi yang membuat lingkungan informasi saat ini menonjol. Prevalensi omong kosong yang emosional membawa daya tarik yang kuat sehingga mampu memikat perhatian dan menghasutkan individu pada narasi (D’Ancona 2017). Meskipun narasi wacana kebohongan terbongkar, pewacana akan menggunakan pembingkaian sebagai informasi yang salah sehingga yang dapat diperbaiki atau dibantah. Prosesi ini setidaknya — secara diam-diammenyiratkan bahwa informasi yang salah adalah cacat pada lanskap informasi, bukan pada kesalahan pewacana. Pada dasarnya, komunikasi politik adalah tentang perpaduan nilai-nilai hiburan dengan nilai-nilai politik (Marshall dan Henderson 2016: 3). Ketika individu terjebak dalam hiburan kepentingan maka akal sehat pun dipertaruhkan. Terlebih pada kondisi masyarakat yang cenderung taken for granted dan memiliki ketidakmampuan intelektual yang peka terhadap fakta, realitas, dan kebenaran.

\section{Informasi yang Salah atau Wacana Alternatif?}

Realitas tentang perkembangan teknologi informasi yang baru kenyataannya menghasilkan informasi yang berlimpah sehingga meningkatkan kesulitan menemukan informasi yang tepat untuk mengevaluasi kualitasnya. Dorongan informasi eksternal nantinya menghambat proses pengetahuan masyarakat yang mapan. Menurut Neuman (1991: 94) media baru dengan banyak informasi realisasinya tidak mengubah orang menjadi pencari informasi yang 
lebih teliti, waspada, dan aktif. Akan tetapi, ledakan informasi ternyata meningkatkan kemungkinan manipulasi karena audiensi dibanjiri dan dihabiskan oleh informasi yang berlebihan. Akibatnya, misinformasi menjadi peluang terbesar hidup di era post-truth. Kesalahan ini terjadi bukan terbatas pada informasi yang salah, melainkan juga tentang kesejahteraan intelektual masyarakat secara keseluruhan.

Pada akhirnya, ungkapan fakta-fakta alternatif mulai diciptakan pada tahun 2017 sehingga menjadi slogan populer di beberapa negara-negara, khususnya Eropa dan Amerika. Fakta alternatif digunakan untuk menggambarkan pernyataan yang diekspresikan baik dalam ketidaktahuan sepenuhnya atau dengan total mengabaikan kenyataan (Strong, 2017: 1). Upaya semacam itu bahkan dapat melumpuhkan narasi faktual, sebab narasi alternatif diklasifikasikan sebagai berita palsu karena tidak sesuai dengan pandangan mayoritas (Bhaskaran, Mishra, dan Nair, 2017: 44). Dengan kata lain, klaim besar tentang era post-truth lainnya juga tidak berusaha membangun model realitas yang koheren. Sebaliknya, semuanya berusaha mengikis kepercayaan pada kenyataan; titik di mana fakta tidak lagi penting atau bahkan tidak diakui ada. Narasi alternatif yang secara faktual menyesatkan dapat melawan efek informasi faktual (McCright et al., 2016).

Meningkatnya frekuensi para aktor politik di banyak negara, termasuk Indonesia, yang mengedarkan fakta-fakta alternatif dalam beberapa tahun terakhir, penting kaitannya dengan munculnya politik post-truth (Strong, 2017). Pergerakan elite politik mengandalkan daya tarik emosional daripada diskusi berbasis fakta. Sejalan dengan pandangan Frankfurt (2005: 54-54) yang melihat esensi tersembunyi dari narasi yang dibuat oleh pewacana sebenarnya bukanlah kebohongan, tetapi manifestasi kepentingannya sendiri tanpa melihat nilai-nilai kebenaran. Pada saat fakta dipilih berdasarkan kenyamanan politik atau realitas digantikan oleh fakta alternatif maka diskursus ruang publik mulai kehilangan otoritas kebenarannya. Kemudian fakta-fakta direduksi menjadi persenjataan strategis dalam perebutan kekuasaan politik; digunakan atau disebarkan, dianggap atau diabaikan, dan diterima atau ditolak sesuai dengan kebutuhan strategis kepentingan politis (Hendricks dan Vestergaard, 2019: 104).

\section{Post-truth dan Wacana Politik: Masalah yang Tersisa}

Meningkatnya problematika tentang perdebatan wacana politik di rezim post-truth ternyata memengaruhi sistem demokrasi di Indonesia. Kapasitas demokratisasi yang diberlakukan setelah orde baru dalam mengatasi dan menyelesaikan masalah-masalah sosial mulai terancam oleh debat politik saat ini. Jika informasi adalah mata uang demokrasi, masalah misinformasi menghadirkan tantangan serius terhadap kualitas pemerintahan yang demokratis (Kuklinski et al., 2000). Ruang publik yang belum sepenuhnya mapan mulai dicederai oleh kepentingan politis. Masyarakat Indonesia dimanfaatkan dalam momentum 
penarikan massa politik melalui fakta-fakta kurang penting yang memicu emosi dan kepercayaan pribadi (Hendricks dan Vestergaard, 2019: 103). Semua masyarakat bisa melihat bahwa pertarungan wacana politik di zaman ini yang ditandai dengan polarisasi politik cukup signifikan dan paparan media sosial yang terus berdatangan (Stroud, 2011).

Di zaman post-truth, kekuasaan terletak pada orang-orang yang paling vokal dan berpengaruh di media sosial. Oleh sebab itu, para politikus banyak yang berusaha menggaet selebritis dan tokoh masyarakat untuk mempromosikan dirinya di masyarakat. Konstruksi pesona yang disebarkan oleh figur ikonik diharapkan mampu membuat ilusi pendapat yang tersebar luas (Lewandowsky et al., 2017: 354). Selain itu, keprihatinan tentang organisasi media dan jurnalis yang mencari, - lebih tepatnya menyenangi - berita palsu yang disebarkan oleh politisi dan kelompok partisan post-truth terutama melalui platform media sosial (Bhaskaran, Mishra, dan Nair, 2017: 44). Sensasionalitas wacana kebohongan menjadi kunci yang selalu direbutkan para awak media untuk mendulang keuntungan sebesar-besarnya.

Kemasan narasi yang sarat kepentingan dan manipulasi kemudian di konsumsi oleh masyarakat Indonesia secara luas. Penekanan pada peristiwa negatif dan liputan persaingan politik yang intens sering kali menghasilkan sinisme dan malaise dan mengarah pada sikap negatif terhadap lembaga politik (Cappella dan Jamieson, 1997). Literasi media yang belum banyak didapatkan masyarakat indonesia nantinya semakin memperburuk kondisi seperti ini. Akibatnya, perpecahan antar kelompok pendukung menjadi momok menyeramkan bagi nilai nasionalisme dan kebhinekaan Indonesia.

Dalam hal ini, banyak antusiasme individu yang mencoba menengahi pertikaian perbedaan politik ataupun misinformasi dengan cara mengkoreksi. Padahal cara tersebut belum sepenuhnya efektif dalam beberapa keadaan; meskipun telah diperbaiki. Ketika koreksi menantang pandangan dunia orang, kepercayaan terhadap informasi palsu bahkan dapat meningkat secara ironis. Pada umumnya, seseorang akan terus bergantung pada informasi yang diketahui salah. Fenomena ini dikenal sebagai efek pengaruh berkelanjutan (Ecker, Lewandowsky dan Tang, 2010; Lewandowsky et al., 2012).

Ketika seseorang percaya bahwa pendapatnya dibagikan intens dan secara luas, maka secara khusus orang tersebut menolak revisi kebenaran dengan kepercayaannya sendiri (Leviston et al., 2013). Individu tersebut cenderung berkompromi dan bersikeras bahwa pandangan seperti dirinya yang berlaku secara universal (Miller, 1993). Sebab, fraksinasi lanskap media yang menjadi ruang gema mendorong banyak orang untuk percaya pendapat mereka, meskipun tanpa bukti yang sahih. Dengan demikian, koreksi hanya efektif ketika memenuhi 
kondisi seperti; pertama, tidak secara langsung menantang pandangan dunia orang, tetapi dengan membuat koreksi lebih persuasif. Kedua, koreksi harus menjelaskan informasi salah yang disebarkan sejak awal atau memberikan penjelasan tentang peristiwa yang relevan.

\section{Meninjau Kembali Ancaman Media di Rezim Post-truth}

Babak baru produksi pengetahuan, distribusi, dan pertahanan kebenaran di era post-truth tidak dapat dibendung oleh masyarakat. Progresivitas periodesasi zaman yang semakin cepat tampaknya telah mengubah budaya politik modern. Ketika individu mengikuti logika yang sesak dengan informasi dan kemudahan mengakses platform digital akan berpengaruh pada kesadaran publik. Dalam hal ini, setiap individu memungkinkan untuk terbenam dalam fantasmagoria informasi yang dikreasikannya sendiri (Sawyer, 2018: 66). Media informasi menyederhanakan proyek demokratisasi sehingga persepsi aksesibilitas yang bebas dirayakan dalam bentuk pertarungan konten media. Potensi partisipatif kelompok produsen teks — dari yang biasa hingga profesional- berusaha membentuk simpul lingkungan informasi dengan potensi untuk mengatur dirinya sendiri. Fenomena ini bukan hanya tentang mentransfer konten, tetapi tentang pembentukan pandangan dunia yang bersifat wacana (KhosraviNik 2017; 2018).

Selain itu, meskipun produksi konten masih melibatkan keterampilan dan sumber daya yang signifikan, kemajuan dalam otomasi dapat membuat proses lebih efisien. Seperti halnya otomatisasi yang mengubah sebagian besar proses produksi sehingga dengan mudah digunakan untuk menciptakan dan menyebarkan narasi (Woolley 2018). Sependapat dengan Sunstein (2009) yang menyatakan bahwa era post-truth telah mengidentifikasi keberadaan ruang gema dan gelembung sumber informasi di dalam ranah virtual. Perkembangan teknologi kognitif, produksi otomatis, dan big data semakin menunjukkan perjalanan masa depan post-truth. Skenario wacana semakin hari mulai difasilitasi oleh algoritma media sosial yang memastikan bahwa artificial intelligent secara otomatis sumber dan menganalisis data, menghasilkan konten presisi dalam format yang diperlukan audiens, kemudian mengumpulkan dan menganalisis umpan balik, serta menyesuaikan kembali konten yang sesuai (lihat Pariser, 2011; Lyon 2014; Wiesenberg et al. 2017).

Kemampuan untuk menggunakan pembuatan konten dengan seleksi algoritmik akan memungkinkan produksi dan modifikasi pesan yang ditargetkan menjadi skala industri baru. Sebab, publik tampaknya semakin menerima cerita yang dihasilkan secara algoritmik, memberikan kredibilitas yang sama kepada yang diproduksi oleh manusia dan algoritma (lihat Wöllker dan Powell 2018). Otomatisasi semacam itu pasti akan membawa post-truth lebih jauh. Meskipun pengguna menggunakan platform digital untuk alasan non-politis, secara tidak sengaja akan tetap menemukan konten politik yang diposting oleh orang lain yang 
terhubung dengan dirinya (Anspach, 2017). Ditambah dengan mesin algoritma yang tidak sepenuhnya dapat mendeteksi berita palsu sehingga situs media sosial seperti Facebook tetap menjadi tempat yang populer dan aman untuk penyebaran narasi kebohongan (Tate, 2016). Semakin sering publik mengakses mengandalkan media sosial sebagai sumber berita maka semakin rentan juga publik terhadap informasi palsu. Dengan kata lain, media sosial di era post-truth menghadirkan ancaman serius sistem demokrasi (Clayton et al., 2019: 2).

\section{SIMPULAN}

Pada konteks ini, terdapat tiga elemen penting yang kurang lebihnya menciptakan kekeruhan kondisi politik di Indonesia sejak tahun 2018 hingga 2019 — pasca-pemilihan umum. Pertama, paradigma post-truth yang menciptakan partkularisme narasi-narasi sehingga memungkinkan adanya kebohongan dalam penangkapan realitas objektif. Kedua, wacana politik yang sebagai manifestasi dari kelompok elite kepentingan; abstrak secara perspektif, materiil dalam produksi berita bohong di media sosial. Ketiga, media sosial yang berperan memediumisasi dari keselururhan konten sehingga sampai di tangan masyarakat. Media sosial, khususnya online, mengarahkan manusia ke era baru pencerahan melalui komunikasi yang mudah diakses secara universal. Gaya hidup digital seperti ini menghawatirkan kondisi masyarakat Indonesia karena dalam jejaring online banyak proyek terorganisir untuk mencemari kesadaran dan mengarahkan politisasi subjek individu.

Dalam memahami asal-usul dunia post-truth tampaknya sangat membutuhkan analisis tendensi politik dan sosial. Ancaman post-truth yang menyerang berbagai elemen kehidupan manusia tampaknya juga membutuhkan pendekatan multidisiplin yang lebih terintegrasi; menggabungkan pemeriksaan mendalam terhadap kognisi, sosial, budaya dengan kemungkinan solusi dari kendala politik saat ini. Penulis juga menyarankan beberapa saran, pertama, adanya lembaga swadaya yang membuat sistem pelacak narasi kebohongan. Kedua, Mempekerjakan ombudsman atau editor yang mengawasi operasi surat kabar dan menanggapi kritik publik. Ketiga, pembelajaran publik tentang cara kerja kampanye berita palsu. Keempat, Pelatihan umum dalam literasi informasi sejak dini. Kelima, pendidikan teknologi untuk mengatisipasi mekanisme gelembung filter otomatis. Keenam, menjamin kebebasan berekspresi di ruang publik demokrasi melalui klaim-klaim rasional. 


\section{DAFTAR PUSTAKA}

\section{Buku dan Jurnal}

Abrahamson, J.B., Arterton, F.C. dan Orren, G.R. 1990. The Electronic Commonwealth: The Impact of New Media Technologies on Democratic Politics. New York: Basic Books.

Anspach, N. M. 2017. The New Personal Influence: How our Facebook Friends Influence the News We Read. Political Communication, 34(4), 590-606.

Bhaskaran, H., Mishra, H., dan Nair, P. 2017. Contextualizing Fake News in Posttruth Era: Journalism Education in India. Asia Pacific Media Educator, 27(1), 41-50.

Biały, B., dan Svetoka, S. 2016. New Trends in Social Media. Riga: NATO StratCom Centre of Excellence.

Block, D. 2019. Post-truth and Political Discourse. Switzerland: Palgrave Macmillan.

Boulianne, S. 2011. Stimulating or Reinforcing Political Interest: Using Panel Data to Examine Reciprocal Effects Between News Media and Political Interest. Political Communication, 28(2), 147-162.

Buckels, E. E., Trapnell, P. D., dan Paulhus, D. L. 2014. Trolls Just Want to Have Fun. Personality and Individual Differences, 67, 97-102.

Cappella, J. N., dan Jamieson, K. H. 1997. Spiral of Cynicism: The Press and The Public Good. New York: Oxford University Press.

Chang, W. 2018. Media Use and Satisfaction with Democracy: Testing the Role of Political Interest. Social Indicators Research, 140(3), 999-1016.

Clayton, K., Blair, S., Busam, J.A. et al. 2019. Real Solutions for Fake News? Measuring the Effectiveness of General Warnings and Fact-Check Tags in Reducing Belief in False Stories on Social Media. Political Behavior. doi: 10.1007/s11109-019-09533-0.

Copsey, N. 2003. Extremism on The Net: The Extreme Right and The Value of The Internet. Dalam Political Parties and The Internet: Net Gain?, ed. R. Gibson, P. Nixon, dan S. Ward. London: Routledge.

Craker, N., dan March, E. 2016. The Dark Side of Facebook: The Dark Tetrad, Negative Social Potency, and Trolling Behaviours. Personality \& Individual Differences, 102, 79-84.

D'Ancona, M. 2017. Post Truth: The New War on Truth and How to Fight Back. London: Ebury Press.

Davis, E. 2017. Post-truth: How We Have Reached Peak Bullshit and What We Can Do About It. London: Little, Brown.

Ecker, U. K. H., Lewandowsky, S., dan Tang, D. T. W. 2010. Explicit Warnings Reduce but do Not Eliminate The Continued Influence of Misinformation. Memory and Cognition, 38(8), 1087-1100.

Elliot, T. S. 1920. The Sacred Wood: Essay on Poetry and Criticism. London: 
Methuen.

Eveland, W. P. 2004. The effect of Political Discussion in Producing Informed Citizens: The Roles of Information, Motivation, and Elaboration. Political Communication, 21, 177-193.

Feldman, L. 2017. How Donald Trump Fits in the 'Post-Truth' World. The Christian Science Monitor. https://www.csmonitor.com/USA/Politics/2017/0126/How-DonaldTrump-fits-in-the-post-truth-world. Diakses pada Tanggal 6 Mei 2019.

Frankfurt, H. G. 2005. On Bullshit. Princeton: Princeton University Press.

Fredal, J. 2011. Rhetoric and Bullshit. College English, 73(3), 243-59.

Garrett, R. K., Weeks, B. E., dan Neo, R. L. 2016. Driving a Wedge Between Evidence and Beliefs: How Online Ideological News Exposure Promotes Political Misperceptions. Journal of Computer-Mediated Communication, 21(5), 331-348.

Gerbaudo, P. 2012. Tweets and The Streets: Social Media and Contemporary Activism. London, England: Pluto Press.

Hannan, J. 2018. Trolling Ourselves to Death? Social Media and Post-truth Politics. European Journal of Communication, 33(2) 214-226.

Harsin, J. 2015. Regimes of Posttruth, Postpolitics and Attention Economies. Communication, Culture and Critique, 8(2), 327-333.

Hendricks, V. F., dan Vestergaard, M. 2019. Reality Lost: Markets of Attention, Misinformation, and Manipulation. Switzerland: Springer Nature Switzerland AG.

Kalpokas, I. 2019. A Political Theory of Post-truth. Switzerland: Palgrave Macmillan.

Kelm, O., dan Dohle, M. 2018. Information, Communication and Political Consumerism: How (online) Information and (online) Communication Influence Boycotts and Buycotts. New Media and Society, 20(4), 15231542.

Keyes, R. 2004. The Post-truth Era: Dishonesty and Deception in Contemporary Life. New York: St. Martin's Press.

KhosraviNik, M. 2014. Critical Discourse Analysis, Power and New Media Discourse. Dalam Why Discourse Matters: Negotiating Identity in the Mediatized World, ed. Y. Kalyango., dan M.W. Kopytowska. New York: Peter Lang.

KhosraviNik, M. 2017. Social Media Critical Discourse Studies (SM-CDS). Dalam Routledge Handbook of Critical Discourse Studies, ed. J. Flowerdew, dan J. Richardson. London: Routledge.

KhosraviNik, M. 2018. Social Media Techno-Discursive Design, Affective 
Communication, and Contemporary Politics. Fudan Journal of the Humanities and Social Sciences, 11(4), 427-442.

Kuklinski, J. H., P. J. Quirk, J. Jerit, D. Schwieder., dan R. F. Rich. 2000. Misinformation and The Currency of Democratic Citizenship. Journal of Politics, 62(3), 790-816.

Laybats, C., dan Tredinnick, L. 2016. Post Truth, Information, and Emotion. Business Information Review, 33(4), 204-206.

Leviston, Z., Walker, I., dan Morwinski, S. 2013. Your Opinion on Climate Change Might Not be as Common as You Think. Nature Climate Change, 3(4), 334-337.

Lewandowsky, S., Cook, J., dan Ecker, U. 2017. Letting The Gorilla Emerge from The Mist: Getting Past Post-truth. Journal of Applied Research in Memory and Cognition, 6(4), 418-424.

Lewandowsky, S., Ecker, U. K. H., dan Cook, J. 2017. Beyond Misinformation:

Understanding and Coping with the 'Post-truth' Era. Journal of Applied

Research in Memory and Cognition, 6(4), 353-369.

Lewandowsky, S., Ecker, U. K. H., Seifert, C., Schwarz, N., dan Cook, J. 2012.

Misinformation and Its Correction: Continued Influence and Successful

Debiasing. Psychological Science in the Public Interest, 13(3), 106-131.

Louw, E. 2005. The Media and Political Process. London: Sage Publications.

Lyon, D. 2014. Surveillance, Snowden, and Big Data: Capacities, Consequences, Critique. Big Data \& Society, 1(2). 1-13.

Mair, J. 2017. Post-truth Anthropology. Anthropology Today, 33(3), 3-4.

Marshall, P. D., dan Henderson, N. 2016. Political Persona 2016: An Introduction. Persona Studies, 2(2), 1-18.

McComiskey, B. 2017. Post-Truth Rhetoric and Composition. Colorado: Utah State University Press.

McCright, A. M., Charters, M., Dentzman, K., dan Dietz, T. 2016. Examining The

Effectiveness of Climate Change Frames in the Face of a Climate Change

Denial Counter-frame. Topics in Cognitive Science, 8(1), 76-97.

McGranahan, C. 2017. An Anthropology of Lying: Trump and the Political Sociality of Moral outrage. American Ethnologist, 44(2), 243-248.

McIntyre. L. 2018. Post-truth. Massachusetts: MIT Press.

Miller, C. T. 1993. Majority and Minority Perceptions of Consensus and Recommendations for Resolving Conflicts about Land Use Regulation. Personality and Social Psychology Bulletin, 19(4), 389-398.

Neuman, W.R. 1991. The Future of the Mass Audience. Cambridge: Cambridge Uni Press.

Ott, B. L. 2017. The Age of Twitter: Donald J. Trump and The Politics of Debasement. Critical Studies in Media Communication, 34(1), 59-68.

Papacharissi, Z. 2015. Affective Publics: Sentiment, Technology, and Politics. 
London: Oxford University Press.

Pariser, E. 2011. The filter bubble: What the Internet is hiding from you. United Kingdom: Penguin.

Prozorov, S. 2018. Why is There Truth? Foucault in The Age of Post-truth Politics. Constellation, 26(1), 18-30.

Romano, A. 2017. Asserting Journalistic Autonomy in the Post-truth Era of Alternative Facts: Reporting on the Orations of a Populist Leader. Asia Pacific Media Educator, 27(1), 51-66.

Sawyer M.E. 2018. Post-Truth, Social Media, and the "Real" as Phantasm. Dalam Stenmark M., Fuller S., dan Zackariasson, U. (eds). Relativism and PostTruth in Contemporary Society. Switzerland: Palgrave Macmillan.

Shapiro. M.J. 1992. Reading the Postmodern Polity: Political Theory as Textual Practise. Minneapolis: University of Minnesota.

Shirky, C. 2008. Here Comes Everybody: The Power of Organizing Without Organizations. New York: Penguin Books.

Sloman, S., dan Fernbach, P. 2017. The Knowledge Illusion: Why We Never Think Alone. New York: Riverhead Books.

Strong, S. I. 2017. Alternative Facts and The Post-truth Society: Meeting The Challenge (University of Missouri School of Law Legal Studies Research Paper No. 2017-04). US: University of Pennsylvania Law Review Online.

Stroud, N. J. 2011. Niche News: The Politics of News Choice. NY: Oxford University Press.

Suiter, J. 2016. Post-truth Politics. Political Insight, 7(3), 25-27.

Sunstein, C. R. 2009. Republic.com 2.0. New Jersey: Princeton University Press.

Synnott, J., Coulias, A., dan Ioannou, M. 2017. Online Trolling: The Case of Madeleine McCann. Computers in Human Behavior, 71, 70-78.

Tallis, B. 2016. Living in post-truth: Power/ Knowledge/ Responsibility. New Perspectives, 24(1), 7-18.

Tate, A. 2016. Facebook's False Reality: Why Fake Political News Is On The Rise. New Statesman, September 9, 17. Accession number 117973830.

Valeriani, A., dan Vaccari, C. 2016. Accidental Exposure to Politics on Social Media as Online Participation Equalizer in Germany, Italy, and The United Kingdom. New Media \& Society, 18(9), 1857-1874.

Virilio, P. 1986. Speed and Politics. New York: Semiotext(e).

Wiesenberg, M., Zerfass, A., dan Moreno, A. 2017. Big Data and Automation in Strategic Communication. International Journal of Strategic Communication, 1(2), 95-114.

Wöllker, A., dan Powell, T. E. 2018. Algorithms in the Newsroom? News Readers' Perceived Credibility and Selection of Automated Journalism. 
Journalism, 1-18.

Woolley, S. 2018. The Political Economy of Bots: Theory and Method in the Study of Social Automation. Dalam R. Kiggins (Eds.), The Political Economy of Robots. London: Palgrave Macmillan.

\section{Koran, Majalah, dan Artikel Internet}

https://katadata.co.id/telaah/2019/04/24/menelisik-perhitungan-real-count-alakubu-prabowo-sandi. Diakses pada tanggal 15 Mei 2019.

https://majalah.tempo.co/read/157570/presiden-republik-indonesia-joko-widodotugas-pemimpin-bukan-memanaskan-suasana. Diakses pada tanggal 15 Mei 2019.

https://nasional.kompas.com/read/2019/01/17/17162721/beberapa-jam-jelang-

debat-pertama-twitter-dipenuhi-tagar-politik. Diakses pada tanggal 15 Mei 2019.

https://nasional.tempo.co/read/1197486/prabowo-sebut-quick-count-bohonglembaga-survei-angkat-bicara. Diakses pada tanggal 15 Mei 2019. https://www.merdeka.com/dunia/jelang-pemilu-facebook-dan-twitter-jadi-medantempur-buzzer-politik-jokowi-prabowo.html. Diakses pada tanggal 15 Mei 2019. 